\title{
Sovereign Wealth Funds of States: Experience, Results and Prospects
}

\author{
Isabella Damdinovna Elyakova*, Nikolai Nikolaievich Tikhonov and Aleksandr Lvovich Elyakov \\ Financial and Economic Institute, M. K. Ammosov North-Eastern Federal University, \\ Sakha Republic, Russia; elyak@list.ru
}

\begin{abstract}
This article analyzes the prerequisites for the emergence of sovereign wealth funds in order to identify the methods and mechanisms for their effective use at the present time, as well as for their preservation and increase in the long term. The novelty of the approach first of all comprises the use of the multivariate correlation and regression analysis method to study the factors, which influence the index under study; the selection of the most important fundamental factors, which affect the volumes of the sovereign funds of Russia; the development of improved methods and mechanisms for the effective use of the sovereign funds of Russia, including at the development of the formula for calculating a safe volume of the resources of the National Welfare Fund of Russia (NWF) with the purpose of investment in the development of the national economy without the threat of its overheating; the substantiation of forecast scenarios of effective utilization of the National Welfare Fund of Russia, depending on the influence of the main factors. The study is relevant because the proposed scientific approaches will allow managing most effectively the resources of the sovereign national wealth funds, ensuring the further development of the economies of countries and improvement of the well-being of citizens.
\end{abstract}

Keywords: Dependence, Effectiveness, Factors, Mechanism, Method, National Welfare Fund of Russia, Sovereign Wealth Fund of a State, Utilization

\section{Introduction}

The objective conditions for the world economy development, including the alternation of periods of economic growth and crises, as well as realization of the need for substitution of exhaustible energy resources with financial investments, stimulated the emergence of the institution of sovereign funds. The prerequisites for the emergence of sovereign funds of countries are revealed by the economic science, which consistently considers the causes, periods and countries of their emergence. The deteriorating macroeconomic situation in the country because of the sanctions of western countries and the United States has caused the need for a more thorough study of the history of occurrence and development of sovereign wealth funds of the state to determine the strategy and develop mechanisms for effective increase and spending of funds.
An analysis of the results of the leading scientists and experts' studies evidences the conducted research of the history and causes of the occurrence of sovereign wealth funds of states.

Sovereign wealth funds in some countries were created as far back as in the 1950s, but only in the beginning of the XXI century, this funds gained due attention. The first theoretical substantiations of their creation and the options of management of the accumulated resources can be found in the work of the Scottish philosopher Adam Smith "Wealth of Nations". The resources that the fund received, according to Smith, were a part of the profit, withdrawn from the earnings of large enterprises 1. The collection of Karl Marx's works has revealed the regularity that the source of sovereign wealth funds is the absolute ground rent. The general favorable trends for the emergence of sovereign wealth funds observed in the postwar period of development of the economies of developed

\footnotetext{
${ }^{*}$ Author for correspondence
} 
countries in 1960s-1980s were high rates of the economic growth, active industrialization and modernization of the economy, determined by the catching-up phenomenon, the beginning of the era of the scientific and technological revolution in the developed countries, and the growth in the price of hydrocarbons. Sovereign wealth funds accumulated revenues in foreign currency from the sale of oil, the influx of which into the economy of countries threatened to cause their overheating, so it was more reasonable to withdraw them from budgets and form investment funds ${ }^{2}$.

In many scientific works dedicated to sovereign wealth funds, the question under study is the prerequisites and causes of their emergence, in what countries this was mostly happening, and what time periods they covered ${ }^{3,4}$. The international practice evidences that sovereign wealth funds are formed mainly by exporters of non-renewable natural resources, as well as by countries that have a chronic surplus of the current account of the balance of payments. Currently, the majority of established sovereign wealth funds, both in terms of the asset volume and in terms of the number in the world, are concentrated in emerging markets, mainly in Asian countries ${ }^{5}$.

The reason for the increasing interest in this type of savings of the government sector was the sharp increase in the volume of their resources: They have become comparable to the international reserves of central banks. For example, as of January 1, 2013, the total value of SWFs reached 5.2 trillion US dollars, yielding half the world's total volume of gold and foreign assets and close to the amount of the reserve assets of developed countries 5 .

From this perspective, the position of A. Sukharev is interesting. According to him, due to a significant replenishment of sovereign wealth funds mainly in developing countries, the total volume of international sovereign funds can increase by $800-900$ billion US dollars annually. The circulation of such large-scale resources in the international capital market has become a subject of research interest of the scientific community and international financial institutions, such as the Institute of Sovereign Funds.

"Sovereign wealth funds" as a general concept mean an economic category. The Sovereign Fund is a fund that is owned and controlled by the state, which accumulates and controls the financial resources of the society 6 . A sovereign fund is understood as a state investment fund, whose financial assets include stocks, bonds, property, precious metals and other financial instruments $s^{5,7}$.
The conceptual and categorical framework of the operation of sovereign wealth funds is systematized mainly in the documents of the International Monetary Fund. They define the basic purposes of these funds, which include the compensatory (compensation of the instability of budgetary revenues related to export earnings because of fluctuations of the international situation), leveling (stimulation of domestic sectors of the economy at the expense of the revenues generated from the export of non-renewable natural resources, formation of the sources of "long money" in the economy); incomegenerating (reaching a higher level of profitability compared to the international reserves through the use of a wider range of financial instruments); redistributive (redistribution of proceeds from the export of nonrenewable natural resources for the benefit of future generations); and stabilizing (the use of sovereign funds' resources in times of crises) purposes.

Суверенный фонд - экономическая категория, выражающая определенные экономические отношения, возникающие между участниками фонда (его учредителями, собственниками, кредиторами, бенефициарами и др.), в процессе формирования, размещения и использования средств (активов) фонда (Панова, 2013)

According to most experts, establishment of a sovereign wealth fund should be clearly stated in the national legislation ${ }^{8}$.

In many scientific works on sovereign funds, the issue of effective use of the accumulated resources of these funds is studied ${ }^{3,5,7,9-11}$. For example, speaking about the effectiveness of the Russian sovereign wealth funds management, we need to note that the management effectiveness can be viewed from the position of the investment strategy used; the position of profitability of such management; the position of marketability of the funds' resources invested in permitted financial assets ${ }^{10}$.

Creation in 2004 of the Stabilization Fund, later transformed into the Reserve Fund and the National Welfare Fund, its role in the monetary and fiscal policy of the state has been reflected in multiple works of Russian researchers ${ }^{3,5,6,9,11-13}$.

\section{Materials and Methods}

In accordance with the classification of the International Monetary Fund, sovereign wealth funds are divided into stabilization funds, funds for future generations, reserve 
investment corporations, development funds and reserve funds. Functionally, these funds may be broken up into two categories:

- Stabilization funds, in a narrow sense, in the common world practice are established to reach the current balance of budgets. In the period of a favorable pricing environment, funds are replenished with contributions from rent payments (in varying proportions depending on the level of world prices). In the circumstances of a deteriorating situation, the accumulated funds are used to finance budget expenditures.

- Savings funds (funds for future generations) are focused on the accumulation of resources for remote purposes - securing budget expenditures in the circumstances of exhaustion of mineral reserves in the future. In addition to rental payments (usually fixed and less dependent on world prices), a significant role in replenishing these funds belongs to revenues from the management of the accumulated funds $s^{5}$.

The problems of sovereign funds are the accumulation of revenues in foreign currency from oil sales, the influx of which into the economy of a country threatens to overheat it.

Despite the relatively short period of existence of sovereign funds, which is six decades long, researchers have identified a number of stages in the formation of state sovereign wealth funds. For example, Ibraev identified three stages of the formation of the funds:

The first stage took place in 1953-1960. The first national welfare fund was the Kuwait Investment Board in London, established in February 1953. The source of funding was the profit from the sale of Kuwaiti oil. Due to the accumulated capital, a system of government control was created, which allowed Kuwait to declare its independence from Great Britain. In 1958, tax revenues from the export of phosphates, the only extracted minerals on Hilbert Islands, were used to establish the Revenue Equalization Reserve Fund of Kiribati.

The second stage took place in 1961-1999. At the late 1990s, there were more than 20 sovereign funds worldwide. During this period, sovereign national welfare funds were established in Norway, Canada, Singapore, the United Arab Emirates and are currently among the largest sovereign wealth funds in the world.

The third stage lasts since 2000 up to now. At the end of 2013, according to the Sovereign Wealth Fund Institute, there were about 82 sovereign wealth funds in the world. The largest sovereign wealth funds of countries are eight of them: The Government Pension Fund of Norway; the
SAMA Foreign Holdings of Saudi Arabia; Abu Dhabi Investment Authority; Investment Corporation of China; Kuwait Investment Authority; the Investment Portfolio of Hong Kong Monetary Authority; the Government of Singapore Investment Corporation; the National Welfare Fund and the Reserve Fund of the Russian Federation.

BRICS countries have also established sovereign funds, such as the Investment Company of China (founded in 2003), the Reserve Fund and the National Welfare Fund of the Russian Federation (founded in 2008) the Investment Portfolio of Hong Kong Monetary Authority (founded in 1998), and the Sovereign Fund of Brazil'.

The aggregate amount of these funds was respectively 4.5 and 5.4 trillion dollars as of 2013 and 2014.

The first sovereign fund in Russia was the Stabilization Fund established on January 1, 2004 in order to stabilize the economy. It was part of the federal budget and targeted to balance it in case if the price of URALS crude oil goes below the base level. On February 1, 2008, the Stabilization Fund of Russia was divided into two parts: The Reserve Fund and the National Welfare Fund (NWF), which have become the current sovereign wealth funds, the total volume of which at the beginning of 2015 amounted to 9.333 trillion rubles.

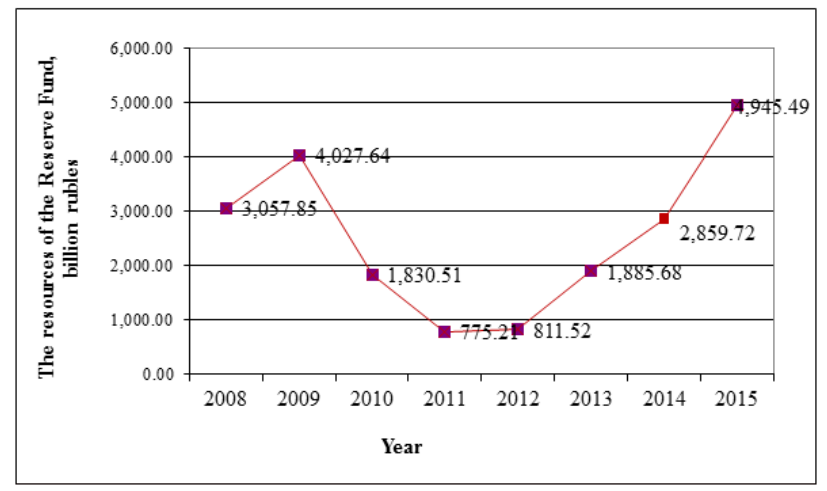

Figure 1. The pattern of changes in the volume of the Reserve Fund of Russia.

Currently, the Reserve Fund is part of the federal budget and is intended to cover its deficit and provide prepayment of the public debt of the Russian Federation. The difference of the Reserve Fund from the Stabilization Fund, which it has actually replaced, is that its income includes gas exports revenues. Figure 1 shows the pattern of changes in the resources of the Reserve Fund of Russia. As of January 1, 2015, the total volume of the National Welfare Fund amounted to 4.945 trillion rubles, which is equivalent to 182.8 billion US dollars. 
Figure 2 shows the total volume of the National Welfare Fund of Russia, which at the beginning of 2015 amounted to 4.388 trillion rubles, or an equivalent of 162.2 billion US dollars.

The National Welfare Fund (NWF) is part of the federal budget resources, dedicated to co-finance voluntary pension savings of citizens and cover the deficit of the Pension Fund of Russia.

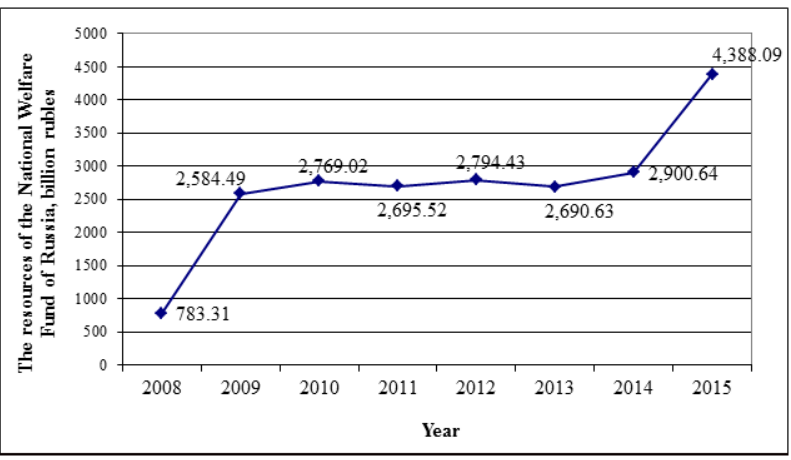

Figure 2. The pattern of changes in the volume of the National Welfare Fund of Russia.

\section{Results and Discussion}

The study identified the main factors influencing the volume of the National Welfare Fund:

- The volume of oil production and consumption in Russia.

- The price per barrel of URALS oil.

- The rate of US dollar to the national currency of Russia-the ruble.

- Table 1 provides the actual changes in production and consumption of oil in Russia, the price per barrel of URALS oil and the dollar/ruble exchange rate in 2004-2014 based on official statistics.

Based on the data in Table 1, the volumes of oil production and consumption in Russia for 14 years grew from 327 to 526 million tons of oil between 2000 and 2014; the price of a barrel of oil tends to grow, except for the sharp decline in oil prices in 2009 caused by the global financial crisis. The dollar/ruble exchange rate according to the Central Bank of Russia changed from 30.7 to 38.61 rubles per dollar for the period from 2004 until 2014.

In order to determine the dependence of the size of the Russian sovereign fund on the oil price and dollar exchange rate, we performed a correlation and regression analysis of the relationship between these parameters.
Table 1. Changes in production and consumption of oil in Russia, the price per barrel of URALS oil and the dollar/ruble exchange rate in 2004-2014

\begin{tabular}{|c|c|c|c|c|}
\hline \multirow[t]{2}{*}{ Years } & \multicolumn{2}{|c|}{ Oil volumes } & \multirow{2}{*}{$\begin{array}{l}\text { URALS } \\
\text { oil price }\end{array}$} & \multirow{2}{*}{$\begin{array}{c}\text { Dollar rate, } \\
\text { rubles }\end{array}$} \\
\hline & Extraction & Consumption & & \\
\hline 2004 & 463 & 116 & 31.02 & 30.70 \\
\hline 2005 & 475 & 119 & 45.21 & 28.28 \\
\hline 2006 & 486 & 117 & 56.32 & 27.18 \\
\hline 2007 & 497 & 112 & 64.28 & 25.57 \\
\hline 2008 & 494 & 114 & 90.68 & 24.85 \\
\hline 2009 & 501 & 113 & 55.61 & 31.82 \\
\hline 2010 & 512 & 114 & 74.11 & 30.44 \\
\hline 2011 & 518 & 114 & 101.74 & 29.34 \\
\hline 2012 & 526 & 117 & 103.14 & 31.00 \\
\hline 2013 & 531 & 113 & 100.41 & 31.85 \\
\hline 2014 & 526 & 118 & 94.22 & 38.61 \\
\hline
\end{tabular}

According to the conducted correlation and regression analysis, the dependencies between the volume of the sovereign fund and the oil price, the volume of Russian sovereign fund and the dollar rate, it was found that:

- The coefficient of correlation between the volume of the sovereign fund of Russia and the oil price is equal to 0.94 ; this means that there is a high correlation between these factors.

- The coefficient of correlation between the volume of the sovereign fund of Russia and the dollar rate is equal to 0.97; this means that there is a high correlation.

We have derived a formula of dependence of the volume of the sovereign fund of Russia on the dollar rate:

$y=0.2228 x 4+3.3056 x 3-16.695 x 2+32.468 x+69.754$

This formula shows the regularity of changes in the volume of the sovereign fund of Russia and the dollar rate, and may be a relative model of this change (in the volumes of the sovereign fund of Russia and the dollar exchange rate). In this model, the actual data on the changes in the volume of the sovereign fund of Russia and the dollar rate show that there is a strong correlation between them:

$\mathrm{R}^{2}=0.97$ (the coefficient of determination at polynomial dependence of the volume of the sovereign fund of Russia on the dollar rate).

As a result, we revealed the prerequisites for creation of sovereign funds and the factors influencing on the creation of sovereign wealth funds of countries to develop the methods of their effective utilization. 
As mentioned above, the National Welfare Fund of Russia was created by dividing the Stabilization Fund into the Reserve Fund and the National Welfare Fund.

The National Welfare Fund is formed by:

- Oil and gas revenues in the form of: The tax on extraction of hydrocarbons (oil, flammable natural gas, gas condensate); export duties on crude oil; export duties on natural gas; export duties on oil products.

- Revenues from the management of the National Welfare Fund's resources.

Since January 1, 2010 and until January 1, 2016, the revenues from managing the resources of the National Welfare Fund are not credited to the Fund, but are directed to cover the expenses of the federal budget.

The existing mechanisms for the utilization of the resources of the National Welfare Fund of Russia are:

- Firstly, maintaining a "financial safety cushion". The existing mechanism comprises the investment of up to $40 \%$ of the fund's resources in foreign currency deposits and highly liquid government bonds of the United States, England and the European Union.

For example, the resources of the NWF were deposited to separate accounts in the Bank of Russia, on which the funds of the National Welfare Fund are accounted, as follows: 24.42 billion US dollars; 23.97 billion euros; 4.35 billion pounds; the deposits in Vnesheconombank accounted for 474.02 billion rubles and 6.25 billion US dollars; 3 billion US dollars were invested in debt securities of foreign countries, without any requirements to the long-term credit rating.

- Secondly, co-financing of voluntary pension savings of Russian citizens and ensuring the balance (offset of the deficit) of the Pension Fund of Russia.

The existing mechanism comprises investing in highly liquid bonds to generate a profit in the amount up to $40 \%$.

- Thirdly, gaining long-term and short-term profit by investing in the Russian Direct Investment Fund (up to $10 \%$ of the funds can be invested);

The existing mechanism assumes directing $0 \%$ of the resources in the Russian Direct Investment Fund.

- Fourthly, gaining a long-term and short-term income by investing in infrastructure projects (no more than $40 \%$ can be invested).

The existing mechanism assumes the investment of $0 \%$ of the resources in infrastructure projects.

As can be seen from the existing mechanisms for the use of resources of the sovereign fund, both during the existence of the sovereign funds of Russia and before them in the form of the federal budget surplus, our state gained almost the same amount of funds, equivalent to the volume of the federal budget revenues, due to the favorable oil prices in the world market, but has failed to use them effectively for the benefit of future generations. These funds were not used to finance the economic growth and the growth of welfare of citizens in order to avoid "overheating the economy", which would threaten an excessive state budget deficit and inflation, caused by excessive financing of the economic growth, high debt ratio, excessive investment of public funds into the economy. But we have failed to find real calculations, substantiated estimates of the effectiveness of such trends and mechanisms in publications. Therefore, we propose to improve the management of the resources of the sovereign wealth fund of Russia. By the example of the National Welfare Fund of Russia, we offer the following methods and mechanisms for the most effective use of the fund's resources in our opinion:

- Firstly, maintaining the "financial safety cushion".

We offer the following mechanism: To invest $45 \%$ of these funds in precious metals (gold and platinum) to preserve the real value of assets and 5\% in highly liquid foreign currency deposits.

- Secondly, co-financing of voluntary pension savings of citizens and coverage of the deficit of the Pension Fund of Russia.

We recommend the following mechanism-portfolio investments in the economies of other countries for income-generation or purchasing interests in foreign companies (China) - up to $15 \%$ of the funds.

- Thirdly, gaining long-term and short-term profit by investing the fund's resources in the Russian Direct Investment Fund (up to $10 \%$ could be invested);

We offer the following mechanism: Investment within $5 \%$ in real estate.

- Fourthly, gaining a long-term and short-term income by investing in infrastructure projects (no more than $40 \%$ could be invested).

We offer the following mechanism: Financing investment projects or direct investment in the economy to develop the agriculture, engineering, aviation industries, etc.up to $30 \%$.

The necessary economic justification of the proposals for the efficient utilization of the resources is to prove that in the future the economy of the country will not be overheated because of the investment of the resources of the Sovereign Fund of the Russian Federation (which are equal to 1.5 trillion rubles) in it in the amount of $35 \%$ of 
Table 2. Changes in production and consumption of oil in Russia, the price per barrel of URALS oil and the dollar/ ruble exchange rate in 2004-2014

\begin{tabular}{cccccc}
\hline Years & \multicolumn{2}{c}{ Oil volumes } & $\begin{array}{c}\text { Oil } \\
\text { price }\end{array}$ & US Dollar exchange rate, rubles & National Wealth Fund volume, million USD \\
\cline { 2 - 3 } & Extraction & Consumption & & & 18.1 \\
2004 & 463 & 116 & 31.02 & 30.70 & 43.4 \\
2005 & 475 & 119 & 45.21 & 28.28 & 93.3 \\
2006 & 486 & 117 & 56.32 & 27.18 & 159.9 \\
2007 & 497 & 112 & 64.28 & 25.57 & 156.81 \\
2008 & 494 & 114 & 90.68 & 24.85 & 152.08 \\
2009 & 501 & 113 & 55.61 & 31.82 & 113.88 \\
2010 & 512 & 114 & 74.11 & 30.44 & 112.0 \\
2011 & 518 & 114 & 101.74 & 29.34 & 150.67 \\
2012 & 526 & 117 & 103.14 & 31.00 & 176.01 \\
2013 & 531 & 113 & 100.41 & 31.85 & 165.91 \\
\hline 2014 & 526 & 118 & 94.22 & 38.61 & \\
\hline
\end{tabular}

the total volume of the National Welfare Fund, including the financing of investment projects or direct investment in the economy for the development of agriculture, engineering, aviation industry (30\%) and in real estate (5\%).

"Overheated economy" is a situation, when the economic growth rate becomes of explosive uncontrollable nature and, having absorbed all the resources of the private and public sectors, reaches the point, at which the sustainable growth exhausts itself and ends up with a recession ${ }^{14}$.

Overheating is preceded by excessive financing of the economic growth, high debt ratio, excessive public investment in the economy, threatening amount of the state budget deficit, inflation, increasingly negative or rapidly lowering value of the foreign trade balance ${ }^{14}$. Economic agents, feeling an approaching recession, prefer to invest in the real economy, for example, in real estate, rather than in financial instruments (bonds, stocks, and so on). Most industrial enterprises by this time almost completely exhaust their (human, research, facility) resources and operate at maximum capacity (people work in two shifts, premises are used other than intended, and so on).

Economy overheating is due to a sudden infusion of funds in the absence of changes in the money supply. But if you change the size of the money supply simultaneously with the start of the investment, it is possible to avoid the overheating. This is a consequence of the fundamental laws of economics - the equation of exchange, described by Irving Fisher in 1911.

To avoid economy overheating and inflation, the following justifying calculations were performed:
The current values of the indicators of Irving Fisher's equation (as of 01.01.2015):

$\mathrm{M}^{\star} \mathrm{V}=\mathrm{P}^{\star} \mathrm{Q}$

wherein:

$\mathrm{V}$ is the velocity of money circulation.

$\mathrm{M}$ is the money supply.

$\mathrm{P}$ is the price level.

$\mathrm{Q}$ is the production volume.

$\mathrm{P} * \mathrm{Q}=$ The annual GDP of the state

As a result, we have: $32,110.5$ billion rubles ${ }^{*} 2.2238$ cycles/year $=71,406.4$ billion rubles

The amount of the National Welfare Fund resources proposed for utilization equals to $1,535.83$ billion rubles (4,388.09 billion rubles $\mathrm{x} 35 \%)$ :

If the velocity of money circulation remains the same and the GDP increases for the amount of the utilized NWF resources, we expect an increase in the money supply by the following amount ( $\mathrm{M}^{\prime}$ is the estimated money supply):

$$
\begin{aligned}
& 2.2238^{\star} \mathrm{M}^{\prime}=71,406.4+1,535.83 \\
& 2.2238^{\star} \mathrm{M}^{\prime}=72,942.23 \\
& \mathrm{M}^{\prime}=32,800.72 \text { billion rubles }
\end{aligned}
$$$$
\Delta \mathrm{M}=32,800.72-32,110.5=690.22 \text { billion rubles- }
$$
this is the volume, by which the money supply will grow.

The proposed increase in the money supply by 690.22 billion rubles will not overheat the economy and will not increase the inflation rate due to the fact that:

- According to the exchange equation of Irving Fisher, the increase in the money supply commensurate with 
the change in the GDP will not change the ruble's purchasing power.

- A steady smooth flow of investments from the National Welfare Fund will allow more effectively managing both investment and money supply. The GDP growth by $1,535.83$ billion rubles will not result in the economy overheating, since to overheat it, larger investment is required-around 2,200 billion rubles (which will increase the necessary money supply by 1 trillion rubles, bringing the economy close to the overheated state).

- It is recommended to invest that money through the federal budget of development, avoiding investing through the banking sector, in order to avoid additional heating of the economy.

In Table 3, we offer our predictive assessment of the NWF incomes in 2020 based on the change in oil prices and the dollar exchange rate in three (baseline, positive and negative) scenarios, where we took the oil production in all three scenarios at a constant level of 408 million tons. The $1^{\text {st }}$ baseline scenario assumes oil at $55 \mathrm{USD} / \mathrm{bbl}$. and dollar at 50 rubles; the $2^{\text {nd }}$ optimistic scenario assumes oil at $70 \mathrm{USD} / \mathrm{bbl}$. and dollar at 45 rubles; the $3^{\text {rd }}$ pessimistic scenario-40 USD/bbl. and 65 rubles, accordingly.

As can be seen, the predictive assessments of incomes of the National Welfare Fund of Russia in the baseline and optimistic scenarios do not differ much, but the pessimistic scenario does, with the low oil price (40 USD/ bbl.) and high dollar exchange rate (65 rubles) causing the volume of the National Welfare Fund to grow by $119.2 \%$ compared to the optimistic scenario, or $120.2 \%$ compared to the baseline scenario of forecast assessment of the Russian National Welfare Fund volume.

\section{Conclusion}

Thus, the main results of the study are:
- Identification of the prerequisites for the emergence and establishment of sovereign wealth funds, where the main reason for the establishment of a national fund was the need to preserve the assets of the nation and future savings.

- Application of a multivariate correlation and regression analysis to explore the factors that influence on the studied index and the selection of the most important fundamental factors influencing on the volumes of Russian sovereign funds.

- Based on the multivariate correlation and regression analysis, identification and analysis of the main factors influencing the volume of the National Welfare Fund of the Russian Federation, such as the change in oil prices in the world market, the dollar to ruble exchange rate and the oil export volumes to determine the estimated volume of the fund.

- Development of improved methods and mechanisms for effective utilization of the sovereign funds of Russia, including the development of the formula for calculating the secure volume of the National Welfare Fund of Russia with the aim of investing in the country's economy development.

- Justification of the forecast scenarios of effective use of the National Welfare Fund of Russia depending on the influence of main factors.

It is important to note that wealth funds are established not only on the country scale, but also in regions. For example, in the Republic of Sakha (Yakutia), the Special-Purpose Fund for Future Generations exists since 1993, and its funds are used for the construction of social facilities. The source for the replenishment of the Fund are unremunerated contributions of ALROSA Group from the profit based on the Agreement on Social and Economic Development of the Republic of Sakha (Yakutia) between the Government of the Republic of Sakha (Yakutia) and ALROSA Group.

We believe that by using international and domestic

Table 3. Predictive assessment of incomes of the National Welfare Fund of Russia

\begin{tabular}{|c|c|c|c|c|}
\hline \multirow[t]{2}{*}{ Factors } & \multirow{2}{*}{$\begin{array}{c}\text { Reporting year } \\
2014\end{array}$} & \multicolumn{3}{|c|}{ Scenarios of the NWF revenues change in 2020} \\
\hline & & Basic & Optimistic & Pessimistic \\
\hline Oil export revenues, million US dollars & $279,856.0$ & $163,363.2$ & $207,916.8$ & $118,809.6$ \\
\hline Oil export revenues, billion rubles & $10,805.2$ & $8,168.16$ & $9,356.26$ & 7,72262 \\
\hline Oil price, USD/bbl. & 94.22 & 55 & 70 & 40 \\
\hline Exports volume, million tons & 408 & 408 & 408 & 408 \\
\hline US Dollar exchange rate, rubles & 38.61 & 50 & 45 & 65 \\
\hline The volume of the National Welfare Fund, billion US dollars & 35.13 & 26.55 & 30.42 & 25.1 \\
\hline The volume of the National Welfare Fund, billion rubles & $1,356.72$ & $1,327.5$ & $1,368.9$ & $1,631.5$ \\
\hline
\end{tabular}


experience in the emergence and formation of sovereign wealth funds, both positive and negative, it is possible in the long term to develop effective mechanisms for accumulation and increase of the national wealth for the benefit of future generations.

\section{References}

1. Smith A. Issledovanie o prirodeiprichinakhbogatstvanarodov [A study of the nature and causes of the wealth of nations]. Moscow: Leningrad. 1935. [in Russian].

2. Sukharev AN. ovyemekhanizmyformirovaniiaiispol'zovaniiasuverennykhfondov [Financial mechanisms of formation and use of sovereign funds]. Finansyikredit[ Finances and Credit];2010; 18:28-33. [in Russian].

3. Ibraev RKh. [Effect of investments of sovereign funds on the value of companies]. Rossiiskoepredprinimatel'stvo[Russian Entrepreneurship]. 2013; 5:227. [in Russian].

4. Sukharev AN. Stabilizatsionnyi fond RF: opytgosudarstvennogosberezheniiaistabilizatsiiekonomiki v 2004-2007 gg. [Stabilization fund of the Russian federation: Experience of state savings and stabilization of the economy in 2004-2007]. Finansyikredit [Finances and Credit]; 2010; 16:41-9. [in Russian].

5. Navoi AV, Shalunova LI. Rezervnyi fond i Fond natsional'nogoblagosostoianiiaRossii $\mathrm{v}$ mezhdunarodnoisistemesuverennykhfondov [Reserve fund and national welfare fund of Russia in the international system of sovereign funds]. Dengiikredit [Money and Credit], 2014; 2:26-33. [in Russian].

6. Panova GS. Sovereign Funds; 2014. Available from: http:// www.gosbook.ru/node/72224
7. Eiskov A. Suverennyefondysobrali 5 trillionovdollarov [Sovereign funds have collected \$5 trillion]; 2013. Available from: http://www.blogs.trust.ua/superinvestor-ru/2013/10/14/968/Su-verennie-fondi-sobrali-5-trillionov-dollarov [in Russian].

8. Savchuk AM. Organizatsionnyeaspektydeyatelnostisyverennykhfondovblagosostoyaniya. [Organizational Aspects of Activities of Sovereign Welfare Funds]. News of V. G. BelinskyPSPU. 2012; 28:514-21.

9. Sukharev AN. Suverennyefondyblagosostoianiia: mezhdunarodnyiirossiiskiiopyt [Sovereign wealth funds: International and Russian experience]. Finansyikredit [Finances and Credit]. 2010; 17:31-7. [in Russian].

10. Duplinskaia EB. SuverennyefondyRossii: analizsituatsii [Sovereign funds in Russia: An analysis of the situation]. VestnikOmskogouniversiteta [Bulletin of Omsk University], 2015; 1: 13-18. [in Russian].

11. Levchenko AV. Suverennyeinvestitsionnyefondykakstabilizatorynatsional'nykhekonomik [Sovereign investment funds as stabilizers of national economies]. VestnikFinansovogouniversiteta [Bulletin of the University of Finance], 2011; 1:67-75. [in Russian].

12. Danilina MV. O formirovanii I upravleniiStabilizatsionnymfondomfederalnogobyudzhetaRossii [On formation and management of the Russian federal budget stabilization fund]. Research Papers: Institute for National Economic Forecasts of RAS. 2004; 2:93-111.

13. Kudrin AL. Stabilizatsionnyy fond: zarubezhnyyirossiyskyopyt [Stabilization fund: International and Russian experience].VoprosyEkonomiki (Economic Matters). 2006; 2:28-45.

14. Arkhipov AI, Bagudina EG, Balashov SA. Ekonomicheskiislovar' [Economic Dictionary]. $2^{\text {nd }}$ ed. Moscow: Prospect Publishing House; 2015. p. 672. [in Russian]. 